\title{
PERLINDUNGAN HUKUM TERHADAP PEMEGANG SAHAM PERSEROAN TERBATAS AKIBAT PUTUSAN PAILIT
}

\author{
Oleh \\ Komang Gede Trisnowinoto* \\ R.A. Retno Murni ${ }^{* *}$ \\ Ni Putu Purwanti*** \\ Program Kekhususan Hukum Bisnis, Fakultas Hukum \\ Universitas Udayana
}

\begin{abstract}
ABSTRAK
Penulisan ini berjudul Perlindungan Hukum Terhadap Pemegang Saham Perseroan Terbatas Akibat Putusan Pailit. Di dalam Metode penelitian ini menggunakan penelitian hukum normatif. Pemegang saham minoritas dan pemegang saham mayoritas memiliki ha katas perusahaa. Pemegang saham mayoritas memeiliki hak dalam mengangkat para pengurus dari perusahaan atau PT, serta mengendalikan perseroan tersebut serta mengambil keputusan di dalam perusahaan termasuk menentukan gaji serta fasilitas para pejabat dalam perusahaan serta memutuskan keuntungan yang boleh dibagikan. Dalam perlindungan hukum pada pemegang saham myoritas sudah terjamin terutama melalui RUPS. Serta pemegang saham minortas perlu mendapatkan perhatian.
\end{abstract}

Kata Kunci: Perlindungan Hukum, Pemegang Saham,Kepailitan

\footnotetext{
* Penulis Pertama Komang Gede Trisnowinoto Mahasiswa FH Udayana Korespondensi : komang.nino@yahoo.co.id

** Penulis Kedua Retno Murni Dosen FH Udayana Korespondensi : retnomurni@unud.ac.id

*** Penulis Ketiga Ni Putu Purwanti Dosen FH Udayana Korespondensi : putu_purwanti@unud.ac.id
} 


\begin{abstract}
This writing is titled Legal Protection of Limited Liability Shareholder Limited Liability Corporation of Bankruptcy Decisions. The research method used is normative legal research. Result of this writing explain, the remaining shareholders are called minority shareholders. The majority shareholders have full rights to the company. The majority shareholders who have the right to appoint company managers and control the company and make important decisions for the company including determining the salaries and facilities of company officials and deciding what benefits to share as dividends. Legal protection for the majority shareholders is guaranteed, especially through the RUPS. While the protection for minority is something new and lack of attention.
\end{abstract}

\title{
Keyword : Legal Protection, Shareholders, Bankrupty.
}

\section{I.I. Pendahuluan}

\subsection{Latar Belakang}

Indonesia menunjukan cendrungan dalam sector swasta, serta adanya serangkaian dergulasi ekonomi, kebnayakan memiliki badan usaha perusahaan atau perseroan (di sebut PT) menjadi lebih dominan dari pada usaha lainnya. ${ }^{1}$

Dalam pasal 1 angka 1 UU No 40 Tahun 2007 tentang perseroan (disebut UU PT) yaitu suatu bandan Hukum, disebut subjek hukum yang memiliki nilai lebih daripada organisasi ekonomi yang lain. Maka dari itu dapat di katakana PT memeiliki nilai lebih ditinjau dari aspek ekomi ataupun aspek yuridis.Dalam aspek tersebut saling mengisi satu sama lain. Aspek hukum

Absori, 1998, Hukum Ekonomi Beberapa Aspek Pengembangan, Surakarta: Universitas Muhammadiyah Surakarta, Hal. 37. 
memberika tanda agar keseimbangan kepentingan semua pihak dapat di jalankan dalam menjalankan kegiatan ekonomi. ${ }^{2}$

Dalam PT terdapat pemegang saham dalam perusahaan dikenal dengan pemegang saham Mayoritas dan pemegang saham Minoritas. $^{3}$

Dalam mengambil keputusan di suatu perusahaan dipastikan pemegang saham minoritas akan selalu kalah dibandingkan dengan pemegang saham mayoritas karena dalam pengambilan keputusan dengan dasar besar persentase saham yang dimiliki. Situsi terbut membuat parah, karena jika pemegang saham melakukan peluang untuk mengendalikan suatu perusahan untuk kepentingn serta tidak mementingkan pemegang saham minoritas. ${ }^{4}$

Suara kuorum atau yang penting agar mengluarkan suaranya terlihat jelas peranan pemegang saham minoritas dan mayoritasterlebih perusahaan jatuh pailit berkaitan delistingnya emiten dari bursa efek. dileting dapat diartikan suatu pencatatan dari daftar saham karena tidak memenuhi ketentuan dalam bursa tersebut. 5

\section{${ }^{2}$ Ibid, Hal. 38.}

${ }^{3}$ Agus Budiarto, Kedudukan Hukum dan Tangung Jawab Pendirian Perseroan terbatas, (Ghalia Indonesia), 2002, cet. Ke-1, Hal. 123-124.

${ }^{4}$ M. Irsan Nasarudin dan Indra Surya , 2004, Aspek hukum pasar modal Indonesia.. Jakarta .Kencana Prenasa Media Group, Hal. 279.

${ }^{5}$ FirdhaAryati, Perlindungan Hukum Terhadap Pemegang Saham Minoritas, https://www.scribd.com/document/343713516/BAB-II, Di Akses Pada Rabu, 21 September 2017. 
Pentingnya perlindungan hukum bagi pemegang saham yang menanamkan sahamnya pada PT menimbulkan problematika yang sangat riskan. Dimana pengaturan dalam UU PT tidak secara jelas di atur, sehingga perlu peraturan hukum yang jelas, khusus, dan spesifik dalam menyelesaikan permasalahan tersebut.

Dari yang di jelaskan dalam latar belakang, dapat ditarik rumusan masalah sebagai berikut :

1. Apakah direksi dapat diminta untuk bertanggung jawab atas kelalaian terhadap perseroan terbatas yang di nyatakan pailit?

2. Upaya hukum apakah bagi pemegang saham pada PT jatuh pailit ?

\subsection{Tujuan}

Penelitian ini memeiliki tujuan adalah sebagai berikut:

1. Untuk mengkaji dan menganalisis Bagaimana akibat hukum Perseroan Terbatas yang dinyatakan pailit

2. Untuk mengetahui mengenai tentang bagaiman upaya hukum pada pemegang saham perseroan terbatas yang jatuh pailit 


\section{ISI MAKALAH.}

\subsection{Metode Penelitian}

Penelitian ini menggunakan yaitu penelitian Normatif yaitu mengkaji bahan dan Peraturan Undang-undang serta bahan lain dari berbagai buku. ${ }^{6}$ Menurut Bambang Sunggono, penelitian hukum normatif atau disebut juga dengan penelitian hukum dogmatic atau teoritis, karena mengandung atau mengkaji implementasi atau pelaksanaan hukum, penemuan hukum didalam perkara perdata atau pidana, sistem hukum, taraf sinkronisasi hukum, perbandingan hukum dan sejarah hukum. ${ }^{7}$

\subsection{Pembahasan}

\subsubsection{Tanggung Jawab Direksi Atas Kelalaian Terhadap Perseroan Terbatas Yang Dinyatakan Pailit}

Perseroan terbatas adalah suatu wadah yang menghimpun seseorang atau orang - orang yang berkerjasama dalam PT, tetapi segala perbuatan atau tindakan yang jalankan dalam rangka kerja sama dalam PT tersebut oleh hukum dapat dipandang sematamata sebagai suatu perbuatan badan hukum. ${ }^{8}$ Tugas serta tanggungjawab yang di jalakan Direksi terhadap PT dan para

6 Soerjono Soekanto dan Sri Mamudji, 2013, Penelitian Hukum Normatif Suatu Tinjauan Singkat, cet. XV, Rajawali Pers, Jakarta, Hal. 13-14.

${ }^{7}$ Sunaryati Hartono, 1994, Penelitian Hukum di Indonesia, Alumni, Bandung, Hal. 139.

${ }^{8}$ Erick Rianto F. Lubis, 2017, Tanggung Jawab Direksi PT Riau Airlines Terhadap Para Pemegang Saham Setelah Gagal Usaha, Vol. IV No. 2 Oktober 2017, Hal. 9, jom.unri.ac.id, URL: https://jom.unri.ac.id/index.php/JOMFHUKUM/article/view/17718, diakses tanggal 28 Januari 2018, Pukul 09.25 Wita. 
pemegang saham PT telah dijalakan sejak PT tersebut mendapatkan status badan dan hukum. Direksi dapat bertindak mewakili PT, maka itu Direksi mempunyai kewajiban yang baik harus dilaksaanakan atau ddilakukan terhadap Direksi. Lalainya direksi didalam menjalakan kewajiban dapat memberikan sanksi atau hukuman yang menimbulkan bertanggung jawab dari anggota Direksi. Yang terkaitan dengan tugas serta kewajiban direksi.

Sesuai Pasal 100 Ayat (1) UUPT, Direksi berkewajiban untuk: ${ }^{9}$

a. Wajib menulis daftar para Pemegang Saham Perseroan yang berisi mengenai keterangan kepemilikan suatu saham didalam PT dari pemegang saham. Daftar yang mengandung keterangann tentang suatu kepemilikan dalam saham oleh Komisaris serta direksi PT dan keluarganya atas setiap saham yang dimiliki oleh bersangkutan didalam PT atau dalam PT lainnya. Risalah RUPS dan Rapat Direksi PT,

b. Menulis keuangan Perseroan serta laporan tahunan

c. Menjaga seluruh risalah, daftar keuangan Perseroan serta dokumen PT lainnya.

Pasal 101 memberikan penjelasan tentang kewajiban Direksi agar

Memeberitahukan tentang saham dimiliki direksi bersangkutan dalam perseroan serta PT lain untuk di catat daftar

${ }^{9}$ Lilik Mulyadi, 2010, Perkara Kepailitan dan Penundaan Kewajiban Pembayaran Utang, Cet. ke-1, Alumni, Bandung, Hal. 105. 
khusus. Direksi yang tidak menjalankan kewajibannya semestinya serta menimbulkan kerugian bagi PT itu. Seorang pemegang kuasa yang menjalankan kewajiban yang didasari kepercayaan oleh pemberi kuasa agar melakukan dengn perjanjian serta peraturan UU yang berlaku, serta pemegang saham PT memeberikan direksi sebagai pemegang kuasa PT tersebut, bertanggung jawab dalam PT pengelolaan PT, dalam menjalankan tugas yang diberikan ddeengan itikad baik. Dalam kelalain atau kesalahan dalam melaksanakan kewajiban direksi. Adapun hak dari pemegang saham agar :10

a. Bersama-sama ataupun perseorangan, mewakili 1/10 pemegang saham PT melaksanakan gugatan atas nama PT ke Pengadilan Negeri kepada anggota Direksi karena atas kelalaiannya menyebabkan kerugiannnpada PT. ini tercantum dalam Pasal 97 Ayat (6) UUPT.

b. Melakukan gugatan langsung secara perseorangan atas nama pribadi pemegang saham terhadap direksi, dalam keputusan ataupun tidnskandireksi PT yng di rugikan yaitu pemegang saham itu sendiri. Terdapat dalam pasal 97 UUPT

Dalam kepailitan pada PT yang dibuat oleh direksi atas kelalaiannya dilihat pada Pasal 104 Ayat (2) UUPT bahwa, didalam kepailitan itu terjadi karena kelalaian Direksi sert harta pailt tidak cukup untuk membayar sluruh kewajiban 
perseroan dalam kepailitan tersebut, setiap anggota direksi secara tanggung renteng bertanggung jawab atas seluruh kewajiban yang tidak terlunasi dari harta pailit tersebut.

Dalam ketentuan Pasal 104 Ayat (3) dinyatakan bahwa, tanggung jawab sebagaimana dimaksud pada Ayat (2) berlaku juga bagi anggota direksi yang salah atau lalai yang pernah menjabat sebagai anggota direksi dalam jangka waktu 5 tahun sebelum putusan pernyataan pailt diucapkan.

Sifat bertanggung renteng karena atas perbuatan pengurusan PT yang dilakukan oleh direksi maupun komisaris yang dilakukan oleh mereka secara menyimpang, direksi bertanggung jawab terhadap pemegang saham dan PT karena atas tindakannya yang berhubungan dengan PT baik langsung maupun tidak langsung dengan PT.

\subsubsection{Perlindungan Hukum Pemegang Saham Perseroan Terbatas Yang Dinyatakan Pailit}

Dalam perusahaan ada kelompok pemegang saham mayoritas dan kelompak pemegang saham minoritas. Pemegang saham mayoritas memiliki prinsip perlindungan hukum yaitu pada mekanisme RUPS, diambil dengan keputsan 
yang diterima oleh mayoritas jika suara diambil dari pemegang saham minoritas ${ }^{11}$

Dalam kompleksitas permasalah di Indonesia masih menggunakan materi yang terlalu umum dan mendasar. Khususnya dalam UUPT pada Pasal 61 ayat (1) serta Pasal 97 ayat (6) yaitu terhadap gugatan Direksi. Dalam pasal tersebut tidak menjelaskan secara khusus tentang substansi pemegang saham yang lebih spesifik, karena di dalam gugatan tersebut harus ada dasar dan alas haknya.

Dalam hal ini pemegang saham menggugat dengan bagian dari akibat keputusan RUPS, direksi maupun dewan komisaris yang merugikan dari pemegang saham dalam PT. Maka dari itu, prasyaratan menggugat PT dan sebaliknya ketidakadaan kerugian menjadi hak pemegang saham di dalam menggugat menjadi gugur. Didalam gugatan pemegang saham diajukan kepada atau terhadap Pengadilan Negeri yang dimana daerah hukumnya meliputi tempat PT yang digugat. Dalam hal ini hak pemegang saham dengan jumlah $1 / 10$ untuk menggugat Direksi karena kelalaian atau kesalahannya menimbulkan kerugian bagi PT. 12

${ }^{11}$ Munir Fuady, 2005, Perlindungan Pemegang Saham Minoritas, CV Utomo, Cet. ke-1, Bandung, Hal. 1.

${ }^{12}$ Ibid, Hal. 12 
Didalam UUPT upaya pemegang saham untuk melindungi haknya apabila dirinya merasa dirugikan disebutkan didalam Paal 61 ayat 1 :

Setiap pemegang saham berhak mengajukan gugatan terhadap peseroan ke Pengadilan Negeri apabila dirugikan karena tindakan perseroan yang dianggap tidak adil dan tanpa alasan yang tidak wajar sebagai akibat RUPS, Direksi, dan/atau Dewan Komisaris.

Serta didalam Pasal 62 ayat 1 menyebutkan bahwa:

Setiap pemegang saham berhak meminta kepada perseroan agar sahamnya dibeli dengn harga yang wajar apabila yang bersangkutan tidak menyetujui tindakan perseroan yang merugikan pemegang saham atau perseroan, berupa :

a. Perubahan anggaran dasar,

b. Pengalihan atau peminjaman kekayaan perseroan yang mempuyai ini lebih dari 50\% (lima puluh pesen) kekayaan bersih perseroan ; atau

c. Penggabungan, peleburan, pengambilalihan, atau pemisahan.

Didalam pasal tersebut tidak menjelaskan secara khusus tentang substansi pemegang saham yang lebih spesifik, karena didalam gugatan harus terdapat dasar serta alasan haknya atau disebut dengan gugatan derivatif. Dalam artinya pemegang saham menggugat adalah bagian dari suatu akibat serta telah terjadi suatu keputusna RUPS, direksi maupun dewan komisaris yang melakukan kesalahan ataupun kelalaian sehinga dapat merugikan PT. 
Dalam hukum kepailitan PT dikenal adanya suatu prinsip yaitu commercial exit from financial distress yaitu dapat diartikan suatu prinsip yang bertujuan untuk melengkapi rasa keadilan bagi debitor dan kreditor. Kepailitan tidaklah alat bagi kreditor untuk melindungi suatu kepentingannya semata-mata. Kepailitan semestinya tidak alat untuk menekan debitor karena didalam prinsipnya adanya aspek-aspek hukum yang memperhatikan kepentingan debitor pada akhirnya untuk meminimalisir kerugian kekayaan debitor, hal ini dapat dilihat dengan adanya suatu ketentuan masa tunggu, ketentuan penundaan kewajiban pembayaran hutang atau yang disebut dengan PKPU, serta ketentuan rehabilitasi. ${ }^{13}$

Berdasarkan ketentuan Pasal 104 UUPT, disebutkan direksi tidak berwenang mengjukan permohoan pailit atas PT sendiri kepada Pengadilan Niaga sebelum memperoleh persetujuanm RUPS, dengan tidak mengurangi sebagaimana diatur dalam UU tentang kepailitan dan penundaan kewajiban pembayaran hutang. Didalam kepailitan kesalahan atau kelalaian dari direksi serta harta pailit tidak mencukupi untuk memenuhi pembayaran seluruh kewajiban perseroan didalam kepailitan tersebut anggota direksi bersama-sama secara bertanggung renteng atau dapat Hal. 280.

${ }^{13}$ M. Irsan Nasarudin, 2004, Aspek Hukum Pasar Modal Indonesia, Kencana, Jakarta, 
disebut bertanggung jawab yang dimana atas seluruh kewajiban yang tidak terlunasi didalam harta pailit tersebut. Tanggung jawab disini berlaku untuk anggota direksi yang lalai atau bersalah serta pernah menjabat sebagai anggota direksi didalam jangka waktu 5 (lima) tahun sebelum putusan pernyataan pailt disebutkan 14

\section{Penutup}

\subsection{Kesimpulan}

Berdasarkan uraian diatas, dapat ditarik kesimpulan yaitu sebagai berikut:

1. Direksi dapat dinyatakan melakukan penyimpangan apabila direksi terbukti melakukan kelalaian dalam perseroan. Tanggung jawab direksi perseroan terbatas dalam hal kepailitan, anggota Direksi serta seluruh anggota Dewan Komisaris PT bertanggung jawab secara bertanggungrenteng atas tindakan hukum setiap kesalahan atau kelalaiannya.

2. Didalam perlindungan hukum terhadap pemegang saham pada PT yang dinyatakan pailit memiliki hak yang telah diatur dalam UU PT yaitu dengan mengajukan gugatan derivatif. Hal. 280.

${ }^{14}$ M. Irsan Nasarudin, 2004, Aspek Hukum Pasar Modal Indonesia, Kencana, Jakarta, 


\subsection{Saran}

1. Pemegang saham yang dirugikan oleh direksi dalam PT seharusnya membuktikan atau terbukti, jika direksi mengakibatkan kesalahan atau kerugian didalam PT tersebut.

2. Perlindungan hukum terhadap pemegang saham akibat putusan pailit diharapkan dalam peraturannya dapat lebih di lengkapi dan mengarah khusus kepada hak-hak pemegang saham. 


\section{DAFTAR PUSTAKA}

\section{BUKU}

Absori, 1998, Hukum Ekonomi Beberapa Aspek Pengembangan, Universitas Muhammadiyah, Surakarta.

Budiarto. Agus, 2002, Kedudukan Hukum dan Tangung Jawab Pendirian Perseroan terbatas, Cet. ke-1, Ghalia Indonesia.

Fuady. Munir, 2005, Perlindungan Pemegang Saham Minoritas, CV Utomo, Cet. ke-1, Bandung.

Hartono. Sunaryati, 1994, Penelitian Hukum di Indonesia, Alumni, Bandung.

Mulyadi. Lilik, 2010, Perkara Kepailitan dan Penundaan Kewajiban Pembayaran Utang, Cet. ke-1, Alumni, Bandung.

Nasarudin. M. Irsan, 2004, Aspek Hukum Pasar Modal Indonesia, Kencana, Jakarta.

Nasarudin. M. Irsan, dan Surya, Indra, 2004, Aspek Hukum Pasar Modal Indonesia, Kencana Prenasa Media Group, Jakarta.

Shubhan. Hadi, 2009, Hukum Kepailitan (Prinsip, Norma, dan Praktik di Peradilan, Cet. ke-2, Kencana Prenada Media Group, Jakarta.

Soekanto. Soerjono dan Mamudji, Sri, 2013, Penelitian Hukum Normatif Suatu Tinjauan Singkat, cet. XV, Rajawali Pers, Jakarta.

\section{JURNAL ILMIAH}

Erick Rianto F. Lubis, 2017, Tanggung Jawab Direksi PT Riau Airlines Terhadap Para Pemegang Saham Setelah Gagal Usaha, Vol. IV No. 2 Oktober 2017,Hal.9,jom.unri.ac.id,URL:https://jom.unri.ac.id/index. $\mathrm{php} / \mathrm{JOMFHUKUM/article/view/17718}$, diakses tanggal 28 Januari 2018, Pukul 09.25 Wita. 


\section{PERATURAN PERUNDANG-UNDANGAN}

Undang-Undang Nomor 8 Tahun 1995 tentang Pasar Modal (Lembaran Negara Republik Indonesia Tahun 1995 Nomor 64, Tambahan Lemabaran Negara Republik Indonesia Nomor 3608).

Undang-Undang Nomor 40 Tahun 2007 tentang Perseroan Terbatas (Lembaran Negara Republik Indonesia Tahun 2007 Nomor 106, Tambahan Lembaran Negara Republik Indonesia Nomor 4756). 